\title{
Correlation between Forced Expiratory Volume One Second and Vital Capacity with V02 Maximum
}

\author{
Siti Khadijah Rahmania, ${ }^{1}$ Tertianto Prabowo, ${ }^{2}$ Putri Tessa ${ }^{3}$ \\ ${ }^{1}$ Faculty of Medicine Universitas Padjadjaran, ${ }^{2}$ Department of Physical Medicine and \\ Rehabilitation Faculty of Medicine Universitas Padjadjaran/Dr. Hasan Sadikin General Hospital \\ Bandung, ${ }^{3}$ Department of Physiology Faculty of Medicine Universitas Padjadjaran
}

\begin{abstract}
Background: Medical students need to cope with their tight schedule, which also demand a good physical fitness to do those activities. Insufficient leisure time and exhausting activities impede students' capacity on having routine physical exercise to maintain their physical fitness. Cardiopulmonary endurance describes a person physical fitness level, and lung function is one basic component of cardiopulmonary endurance. Without optimal lung function, circulatory system in the body cannot work properly. This study aimed to determine whether lung function giving a significant correlation with the cardiorespiratory endurance which are measured by Forced Expiratory Volume One Second (FEV1), Vital Capacity (VC), and V02Maximum (V02max), respectively.

Methods: This study was conducted in September-October 2013 to the students of Faculty of Medicine at Universitas Padjadjaran academic year 2010-2012, using the cross-sectional method. Sample was taken through simple random sampling process. There were 34 male and 34 female students after controlling for covariates. Direct measurement using spirometer used to determine lung function and maximum oxygen uptake was measured by assessing Rhyming Step Test result. Correlation coefficient was then calculated by Pearson correlation test.

Results: The correlation between FEV1with V02max of male students giving a value of $\mathrm{p}=0.442$, while for $\mathrm{VC}$ obtained a value of $\mathrm{p}=0.259$. Female students result giving a value of $\mathrm{p}=0.746$ for the FEV1with VO2max, and $\mathrm{p}=0.489$ for the VC with the VO2max.

Conclusions: There is no significant correlation between FEV1 and VC with the VO2max of the respondents. [AM].2016;3(3):430-3]
\end{abstract}

Keywords: Forced expiratory volume one second, maximum oxygen uptake, vital capacity

\section{Introduction}

Cardiopulmonary endurance defined as the ability of the circulatory system, respiration, and muscles to deliver oxygen and nutrients efficiently into cells through the bloodstream during a constant physical activity. ${ }^{1}$ The VO2 maximum (VO2max) is one of the indicators in measuring the resistance level of the heart and lung which could determine a person's physical fitness. The result of VO2max affected by oxygen transport capability, power of cardiac pumping, pulmonary ventilation, and the use of oxygen in the muscles. ${ }^{2}$

One basic component of cardiopulmonary endurance itself is the lung function. Lung function at a young adult age, can predict airway obstruction in 20 years ahead.3 Recent international survey identified an airway obstruction on nearly $4 \%$ of young adults aged 20-44 years. ${ }^{4}$ Lung function is associated with respiratory processes, one of them is pulmonary ventilation. To keep the body work normally, it takes the optimal work of the heart and lungs. ${ }^{2}$ Cardiopulmonary endurance requires a synchronized work between circulatory and respiratory systems.

In regards to the lung function as the basic component of cardiopulmonary endurance itself, however, it is still quiet questionable about its significant correlation. As we know that there is another influencing factors related with person's cardiopulmonary endurance which might giving more impact on the outcome. The pulmonary function, also has some determining components. For example,

Correspondence: Siti Khadijah Rahmania, Faculty of Medicine, Universitas Padjadjaran, Jalan Raya Bandung-Sumedang Km.21, Jatinangor, Sumedang, Indonesia, Phone: +6282120887117 Email: skrahmania@gmail.com 
some of its important factors are lifestyle and physical activity. According to Prakash et al. ${ }^{5}$ people with sedentary lifestyles have lowest pulmonary function. Sedentary lifestyle is also associated with development of restrictive lung function and cardiovascular morbidity. Improvementin pulmonary functions is noticed as a result of physical activity. ${ }^{6}$ This study aimed to determine whether lung function giving a significant correlation as one of the factors which underlie the cardiorespiratory endurance. Those are measured by Forced Expiratory Volume One Second (FEV1) and Vital Capacity (VC) to assess the pulmonary ventilation, and VO2 Maximum (VO2max) for the cardiorespiratory fitness.

\section{Methods}

This study has been approved by Health Research Ethics and carried out from September until October 2013, where the samples were students of Faculty of Medicine at Universitas Padjadjaran academic year 2010-2012. The samples were taken by simple random sampling method. After meeting the inclusion criteria, student who had a good vital sign, Body Mass Index (BMI) between 18.5-23 $\mathrm{kg} / \mathrm{m}^{2}$, was not an active smoker, and ready to follow the study by filling the informed consent was participated in the study. Student who could not attend the examination was excluded from the study.

Total number of samples for this study were 68 students, which consist of 34 females and 34 males. As this analytical study could obtain the data within one time measurement, the data was collected with cross-sectional design. Lung function which represented by the FEV1 and VC measured using spirometry method and VO2 Maximum was determined using the Astrand Rhyming Step Test method. ${ }^{7}$ The data was analyzed through statistical tests to determine the correlation coefficient, calculated using Statistical Product and Service Solutions 15.0. by Shapiro-Wilk normality test and Pearson correlation test.

\section{Results}

Among male subjects, 33 students showed a normal category of lung function, only 1 student had mild obstructive category. As many as 4 males showed the maximum VO2 values in the low category, 4 males is quite

Table 1 Characteristic of the Subjects

\begin{tabular}{|c|c|c|}
\hline & $\begin{array}{l}\text { Mean } \\
(\mathrm{X}) \\
\end{array}$ & $\begin{array}{c}\text { Standard Deviation } \\
( \pm \text { SD) }\end{array}$ \\
\hline \multicolumn{3}{|l|}{ Male $(n=34)^{*}$} \\
\hline Age & 20 years & 1.07 \\
\hline Height & $170.5 \mathrm{~cm}$ & 4.90 \\
\hline Weight & $62 \mathrm{~kg}$ & 5.97 \\
\hline $\mathrm{BMI}^{* *}$ & $21.3 \mathrm{~kg} / \mathrm{m} 2$ & 1.53 \\
\hline FEV1 ${ }^{* * *}$ & $3462 \mathrm{ml} / \mathrm{s}$ & 494.14 \\
\hline VC\# & $3853 \mathrm{ml} / \mathrm{s}$ & 607.31 \\
\hline V02 Maximum & $51.91 \mathrm{ml} / \mathrm{kg} / \mathrm{m}$ & 14.05 \\
\hline \multicolumn{3}{|l|}{ Female $(\mathrm{n}=34)^{*}$} \\
\hline Age & 20 years & 1.10 \\
\hline Height & $157.9 \mathrm{~cm}$ & 4.71 \\
\hline Weight & $51 \mathrm{~kg}$ & 5.24 \\
\hline $\mathrm{BMI}^{* *}$ & $20.5 \mathrm{~kg} / \mathrm{m} 2$ & 1.79 \\
\hline FEV1*** & $2338 \mathrm{ml} / \mathrm{s}$ & 430.70 \\
\hline VC\# & $2653 \mathrm{ml} / \mathrm{s}$ & 366.32 \\
\hline V02Maximum & $46.01 \mathrm{ml} / \mathrm{kg} / \mathrm{m}$ & 10.87 \\
\hline
\end{tabular}

Note: ${ }^{*} \mathrm{n}=$ Number of Subjects, ${ }^{* *} \mathrm{BMI}=$ Body Mass Index, ${ }^{* * *} \mathrm{FEV1=Forced} \mathrm{Expiratory} \mathrm{Volume} \mathrm{One} \mathrm{Second,} \mathrm{\# VC=Vital}$ Capacity 
Table 2 Correlation between FEV1 and VC to the V02 Maximum

\begin{tabular}{lcc}
\hline & \multicolumn{2}{c}{ VO2 Maximum } \\
\cline { 2 - 3 } Male & $\mathrm{r}$ (correlation coefficient) & $\mathrm{p}$ (Sig. 2 tailed)* \\
FEV1 & 0.136 & 0.442 \\
VC & 0.199 & 0.259 \\
Female & & 0.746 \\
FEV1 & 0.058 & 0.489 \\
VC & 0.123 & 0.48 \\
\hline
\end{tabular}

Note: ${ }^{*}$ p value $<0.05$ giving significant correlation

low, 12 medium, 4 high, and 10 very high. On the female subject, 32 students had normal category of lung function, and 2 students had mild obstructive category. As many as 5 females showed a quite low maximum VO2maxvalues, 10 moderate, 6 high and 13 very high.

As the standard of lung function values (FEV1 and VC) and cardiorespiratory endurance (VO2max) is difference between male and female, the correlation analysis will be separated by gender. Age of the subjects ranged from 17 to 22 years old with the mean age 20 years old. Each subject had a normal category of BMI, and the mean of VO2max was above the average value for each gender classification (Table 1).

It could be concluded that correlation between FEV1 with VO2max in both male and female students result did not have a significant correlation (obtained a value of $\mathrm{p}=0.442$ and $p=0.746)$. There was also no significant correlation between VC with V02max in both male and female students result (obtained a value of $p=0.259$ and $p=0.489$ ) (Table 2 ).

\section{Discussion}

Gender was considered to be the risk factor As the result given, it is concluded that lung function does not contribute a significant correlation with the cardiopulmonary fitness, and other several factors must be taken into consideration. For example; the physical factors (age, height, weight, sex and body size), genetic, physical exercise, environment, diet and smoking. ${ }^{11,12}$ There are several factors that could not be controlled in this study which are genetic factors, environment and diet. Thus, these uncontrolled factors can be biased the result and affected the outcome.

The circulation system components such as oxygen carrying capacity, the heart pumps and the use of oxygen in the muscle might have a greater influence to the V02max. ${ }^{1}$ Based on Doewes ${ }^{13}$ research about the most dominant contribution factor of body systems to the physical fitness, it is said that the respiratory system only contributed the effective contribution of $12.32 \%$ compared to $36.97 \%$ for the cardiovascular system and 49.29\% oxygen carrier systems. The result was supported by the study conducted by Charususin ${ }^{10}$ which stated that physical activity level as one of the determining factors on physical fitness, had no correlation with pulmonary function.

The range of BMI on the subject have been grouped to matched the category of normal weight to minimize the bias, but the height and weight variations could still affect the results of cardiopulmonary fitness. The gender factor was also has been distinguished.

Lung function which was measured by FEV1 and VC also had several influencing factors. The form factor is the anatomy of the body height and weight, the position for measurement of pulmonary function, respiratory muscle strength, also the lung and chest muscle development. ${ }^{8}$ Some factors that could affect the VC are age, gender, physical exercise, pregnancy, and pathological state. ${ }^{9,10}$ Spirometry results are also dependent to subjects' effort and consistency. Therefore, respiratory muscle strength and the range of respondent's physical exercise must be taken into consideration.

Other limitations in this study included the time of measurement in the subjects. In relation to the academic schedule differences between subjects, the researcher's ability to take the data could not be measured in the same day. According to some experimental studies about the effect of diurnal variation 
in relation to circadian rhythm, it is suggested that VO2 responses are affected by the time of day and could be related to variability in muscle activity pattern. The time-of-day effect on performances is giving a better aerobic participation in energy production during afternoon than in the morning. ${ }^{14-16}$ Therefore, the researcher suggests to measure subjects' VO2 Maximum in the same time to minimize the bias.

Statistical test results showed that lung function (FEV1 and VC) had no significant correlation to the level of cardiorespiratory endurance (VO2max) in both male and female subjects. In a correlative analytical research, the sample size greatly affected the results of the correlation coefficient. In addition, the variability of the data was also one of the factors that can give significant correlation of coefficient results. In this study, the distribution of the data might not have a good variability due to sample size and the results were less centrally within normal values.

Those discussions above might be the reason why there was no significant correlation between FEV1 and VC with the V02max. Therefore, further research with more precise measurement is needed. Some other influencing factor might be giving a significant correlation to the cardiopulmonary endurance.

\section{References}

1. Lee D, ArteroEG, Sui X, Blair SN. Review: Mortality trends in the general population: the importance of cardiorespiratory fitness. J Psychopharmacol. 2010;24(4 suppl):27-35.

2. Plowman SA, Smith DL. Exercise Physiology for Health, Fitness, and Performance. $2^{\text {nd }}$ ed. Philadelphia: Wolters Kluwer Health/ Lippincott Williams \& Wilkins; 2008. p. 383-408.

3. Kalhan R, Arynchyn A, Colangelo LA, Dransfield MT, Gerald LB, Smith LJ. Lung function in young adults predicts airflow obstruction 20 years later. Am J Med. 2010;123(5):468. e1-7.

4. De Marco R, Accordini S, Cerveri I, Corsico A, Sunyer J, Neukirch F, et al. An international survey of chronic obstructive pulmonary disease in young adults according to GOLD stages. Thorax. 2004;59(2):120-5.

5. Prakash S, Meshram S, Ramtekkar U. Athletes, yogis and individual with sedentary lifestyles; do their lung function differ?. Indian J Physiol Pharmacol. 2007;51:76-80.

6. Fatima SS, Rehman R, Saifullah YK. Physical activity and its effect on forced expiratory volume. J Pak Med Assoc. 2013;63(3):3102.

7. Balai Kesehatan Olahraga Masyarakat. Prosedur pengukuran rhyming step test bangku astrand. Bandung, Jawa Barat: BKOM;2003.

8. Guyton AC, Hall JE. Textbook of medical physiology. Philadelphia, Pennsylvania: Elsevier Inc; 2006.p. 471-82.

9. Chakrabarty AS, Chakrabarty K. Fundamentals of respiratory physiology. New Delhi: I.K. International Publishing House Pvt. Limited; 2007.p. 1-21.

10. Pal GK. Textbook of Practical Physiology. $2^{\text {nd }}$ ed. Chennai: Orient Black Swan; 2006.p. 138-154.

11. Noppawan C, Suwannee J, Pipop J, Saipin P. The pulmonary function and respiratory muscle strength in Thai obese children. Siriraj Med J. 2006;59:125-130.

12. Sagiv MS. Exercise cardiopulmonary function in cardiac patients. London: Springer; 2012.p. 1-55.

13. Jayaprakash CS. Sports medicine. New Delhi, India: Jaypee Brothers, Medical Publishers; 2003.p. 174-9.

14. Doewes M, Kiyatno, Suradi. Kontribusi sistem respirasi terhadap VO2 Maks. J Respir Indo. 2011;31(1):10-3.

15. Souissi N, Bessot N, Chamari K, Gauthier A, Sesboüé B, Davenne D. Effect of time of day on aerobic contribution to the $30-\mathrm{s}$ Wingate test performance. Chronobiol Int. 2007;24(4):739-48.

16. Brisswalter J, Bieuzen F, Giacomoni M, Tricot V, Falgairette G. Morning-toevening differences in oxygen uptake kinetics in short-duration cycling exercise. ChronobiolInt. 2007;24(3):495-506.

17. Mosavi SS, Nejati MM, Akaberi S, Jamaat K, Nazari M, Eghbalmoghanlou A. Effect of time of day on aerobic responses with high intensity exercise in volleyball players EuroJ Exp Bio. 2012;2(4):872-74. 